\title{
Mitodologia em Arte: afeto catalisador na criação cênico-pedagógica de Yriadobá
}

\author{
Adriana Rolin' e Luciana Lyra"
}

Resumo: Este artigo é composto por duas epístolas sobre a criação da performance Yriadobá, parte da pesquisa de mestrado, defendida em 2019, na linha Arte, pensamento e performatividade (PPGArtes-UERJ). Urdido em escrita performativa, o texto debate o aspecto curativo da arte, acostando-se do conceito afeto catalisador, de Nise da Silveira..

Palavras-chave: Afeto Catalisador. Nise da Silveira. Mitodologia em arte. Yriadobá.

\section{Mythodology in Art: catalytic affect in Yriadobá scenic-pedagogical creation}

\begin{abstract}
This article is composed of two epistles on the creation of Yriadobá performance, part of the master's research, defended in 2019, in the line Art, thought and performativity (PPGartes-UERJ). Woven into performative writing, the text debates the curative aspect of art, leaning against Nise da Silveira's concept of catalytic affect.
\end{abstract}

Keywords: Catalytic Affection. Nise da Silviera. Mythology in art. Yriadobá.

I Atriz e escritora. Doutoranda e Mestra em Arte pela Universidade do Estado Rio de Janeiro (PPGArtes/UERJ). Arteterapeuta junguiana. Pesquisadora do grupo MOTIM - Mito, rito e cartografias feministas nas artes (CNPq). Discente da Universidade do Estado do Rio de Janeiro - Rua São Francisco Xavier, 524 - Maracanã, Rio de Janeiro - RJ, 20943-000. E-mail: adrianarolin@hotmail.com. Lattes iD: http://lattes.cnpq.br/9158957260741138. Rio de Janeiro, Brasil.

II Atriz, encenadora, diretora, dramaturga e escritora. PhD. em Artes Cênicas (UFRN) e Antropologia (USP). Doutora e Mestra em Artes da Cena (PPGAC/UNICAMP). Pesquisadora-líder do grupo MOTIM - Mito, rito e cartografias feministas nas artes (CNPq). Coordenadora e Docente do Programa de Pós-graduação em Artes da Universidade do Estado do Rio de Janeiro (UERJ), docente adjunta do DEACP, na mesma universidade - Rua São Francisco Xavier, 524 - Maracanã, Rio de Janeiro - RJ, 20943-000. E-mail: lucianalyra@gmail.com. ORCID: https://orcid.org/0000-00015440-5482. Lattes iD: http://lattes.cnpq.br/5443015479907169. Rio de Janeiro, Brasil. 
São Paulo, 13 de maio de 2021 (tempos pandêmicos).

Querida Adriana,

Em março de 2021, fez um ano que você ingressou no curso de doutorado em artes, no PPGArtes-UERJ, também sob minha orientação. Emociona-me sentir a continuidade de sua pesquisa, pensar que agora seu trabalho com teatro toma parte das ações pedagógico-terapêuticas oficiais do Museu de Imagens do Inconsciente (MII), no bairro do Engenho de Dentro, no Rio de Janeiro. Comove-me que junto ao museu você esteja desenvolvendo um ateliê terapêutico, a partir dos Influxos Artaudianos com os clientes ${ }^{1-}$ artistas que formam o grupo Os Inumeráveis ${ }^{2}$. Enternece-me que você seja catalisadora de afetos dentre essas pessoas imersas em distúrbios psíquicos, experienciando procedimentos que nos remontam proposições do mundo do teatro de Antonin Artaud, e mais, que transitam pelo panteão da mitologia iorubana, lembrando-nos que uma parcela majoritária dos clientes do museu são pessoas negras, mestiças, pobres, e que se movem, na maioria das vezes, guiadas por imagens e narrativas negras ancestrais.

Sua pesquisa no museu me faz lembrar do movimento de Artaud rumo às manifestações dançadas de Bali, com intuito de perceber o índice de vida ali efervescente, e que a arte francesa formalizada já carecia, no princípio do século XX. O seu contato com os clientes do museu, a meu ver, recobra também essa potência desejada, em especial, quando intensificada por experiências cênicas guiadas por mitos advindos de constelações próprias, de África, de Brasil. Na minha dissertação de mestrado, remontando a ação de deslocamento de Artaud, cito Pronko:

(...) Artaud não era louco a ponto de acreditar que a manifestação de um temperamento estrangeiro, como as danças balinesas, que desenvolveram lentamente suas tradições a custo de centúrias, poderia ser transplantada, como parte integrante de nossa cultura ocidental (...). Nosso problema é, antes, o de encontrar, para o nosso próprio teatro, os equivalentes daquelas manifestações. (apud LYRA, p. 63, 2005).

Regressando no tempo, lembro que foi você quem me levou a primeira vez no MII. Eu estava ansiosa. Seria meu momento iniciático frente à uma

1 Termo utilizado por Nise da Silveira para pessoas em sofrimento psíquico, frequentadoras do MII.

2 "O ser tem estados inumeráveis e cada vez mais perigosos." (Antonin Artaud. In: Cahiers d' Art, 1951). Nise (1986) acredita que através da sua própria experiência Artaud conseguiu, melhor do que ninguém, exprimir, por meio da palavra, as suas vivências internas. 
obra densamente edificada sob o tripé afetividade, atividade e liberdade por uma conterrânea minha, do Nordeste, a Dra. Nise da Silveira. Alagoana de nascença e aguerrida nas suas investidas no campo da saúde mental, Dra. Nise sempre teve para mim uma jornada modelar. Suas ações lembram minha mãe ${ }^{3}$ paraibana, psicóloga e psicanalista em flerte ousado com a arte. Guiada por Nise também eu, pernambucana de origem, arvorei-me a pensar a arte na interface com outros campos de saberes, inclusive com a psicologia, experimentando, dentre outros procedimentos, a criação de mandalas no meu trabalho de urdidura dramatúrgica e cênica.

Lembro que no dia em que fui ao museu a primeira vez, senti uma emoção singular. Mergulhando entre as obras de Fernando Diniz, Adelina Gomes, Carlos Pertuis, dentre outras e outros especiais artistas do MII, sorvi os encantados engendramentos produzidos pela arte em meio a um quadro, em princípio, de desesperança. Participando do legendário centro de estudos e pesquisa na área da saúde mental, fundado por Dra. Nise, em 1952, e hoje coordenado por Gladys Schincariol, fui aos poucos adentrando ainda mais no universo niseano.

Voltei ao museu algumas vezes depois, e sempre ao seu lado, você como guia, apresentando-me a singulares investigadores, como o diretor do Museu de Imagens do Inconsciente (MII), Luiz Carlos Mello, e o Prof. Dr. Maddi Damian (UFF), abrindo-me portais para ministrar uma palestra no grupo de estudos, no discorrer sobre a minha pesquisa com a Mitodologia em Arte. Ali também vi nascer parte de sua Yriadobá, entre pesquisadores, pesquisadoras e clientes.

Sobre Mitodologia em arte e Yriadobá quero falar adiante, e um tanto mais, até porque são elas também palavras-chave desta carta, assim como tomam seu título. Mas antes quero pensar ainda sobre Nise, em especial, acerca do conceito/prática Afeto catalisador, que ela veio a desenvolver durante as suas investigações e que, na minha compreensão, tem total relação com a Mitodologia em arte e a criação de sua performance.

Para falar de Nise e seu trabalho no campo da saúde mental, precisamos retornar ao ano 1946 e às condições precárias do universo da psiquiatria no Brasil, no que tange ao tratamento de pacientes em hospitais e centros. Entre as diversas atividades que Dra. Nise desenvolveu em prol da humanização de 
tratamento psiquiátricos, destacaram-se as expressivas, de cunho artístico. Li em suas memórias, que a intenção era criar as condições necessárias para a expressão de ideias e emoções. Esse método terapêutico tinha como meta a reabilitação. E na esteira desse seu pensamento lembro de outro mestre meu, Renato Cohen, ao nos indicar que:

A arte lida com verdade, lida com a transcendência, lida com imanência, é um dos veículos para o ser humano tomar contato com estados superiores de consciência. (2007, p. 163).

Também em contato com as memórias de Nise, presenteadas gentilmente em forma de livro pelo seu autor Luiz Carlos Mello, numa das minhas idas ao museu, estudei que foi no ano de 1952, em decorrência da expressiva produção artístico-científica dos ateliês de pintura e de modelagem, que Nise da Silveira fundou o Museu de Imagens do Inconsciente (MII). Além de dar visibilidade a essas obras, esse espaço se constituiu como um campo ímpar de produção, visto que abriga, em seu interior, um ateliê onde os artistas expositores executam suas obras, afirmando-se, assim, como um Museu Vivo.

Como já mencionei, o método de trabalho de Nise da Silveira foi fundamentado no tripé terapêutico composto pelas categorias afetividade, atividade e liberdade (MELO, 2001; 2010). Nise da Silveira se opôs ao legado filosófico de Descartes que atribui grande importância à racionalidade em detrimento da afetividade. No campo da medicina, essa ruptura entre razão/ emoção, transfigura o corpo em máquina, sendo o médico uma espécie de mecânico que passa a atuar por meios físico-químicos para mantê-lo em bom funcionamento, desestimando, assim, as emoções.

Na contracorrente deste pensamento, Nise da Silveira vem abordar a questão da afetividade com afinco, apontando procedimentos na sua terapêutica, em especial no universo da psiquiatria. Neste sentido ela aponta que: o ambiente médico deve ser acolhedor; a função do terapeuta se constitui a partir das relações afetivas (catalisadoras e inibidoras); e justo a partir do ambiente e das relações são impulsionadas as forças autocurativas da psique. $\mathrm{O}$ afeto cria assim, as condições fundamentais para que pessoas psiquicamente cindidas alcancem novas constelações (MELO, 2001; 2010; SILVEIRA, 1981; 1992).

Em analogia às reações que acontecem na esfera química, o afeto foi abordado por Nise da Silveira $(1981 ; 1992)$ como catalisador ou inibidor dos processos psíquicos. Um terapeuta pode atuar junto à pessoa em sofrimento psíquico em ação catalisadora, liberando a reorganização psíquica, e de forma inibidora junto a outra pessoa, uma vez que as experiências afetivas 
estão ligadas às projeções inconscientes intrínsecas às relações. Dessa forma, a presença de terapeutas (humanos e animais) nas ações tratativas está articulada necessariamente ao conceito de afeto catalisador, estreitando as ligações entre espaço cotidiano e espaço imaginário, entre mundo externo e mundo interno.

Indubitavelmente, Adriana, a afetividade desvela-se como uma das colunas do trabalho de Dra. Nise. Numa filiação clara à ideia spinoziana de afecção, a proposição dela é apreender como o ambiente e as relações nos alcançam subjetivamente. A partir de uma perspectiva niseana, o intenso sofrimento é contrapesado por espaços afáveis e ligações afetivas que fomentam, de forma criativa, conteúdos psíquicos, em oposição às tensões conferidas aos que sofrem psiquicamente. O sofrimento adquire, portanto, sentido e pode ser suplantado pela via do afeto, por isso a significativa importância da atividade artística no empreendimento terapêutico de Nise. Exato porque pelo caminho da arte pode-se acessar a expressão subjetiva de experiências não verbalizáveis por aqueles que, segundo a autora, encontram-se mergulhades nas profundezas do inconsciente (SILVEIRA,1981).

Em contato com as memórias de Nise, suas ações e teorias, há mais de uma década, encaminhei-me à minha própria práxis no campo da arte, que creio esteja absolutamente vinculada às proposições desta médica brasileira. Em concordância com Dra. Nise, entendo que estamos todes mergulhades no coração do inconsciente, e para pessoas em sofrimento psíquico este mergulho é profundo, confuso e sua articulação com mundo consciente é árduo. Mas para artistas, a submersão, a meu ver, é necessária para um pleno ofício, para aguçar sua alma, como nos diz Artaud a seguir, no que se refere ao trabalho do ator:

A crença em uma materialidade fluídica da alma é indispensável ao ofício do ator. Saber que uma paixão é matéria, que ela está sujeita às flutuações plásticas da matéria, dá sobre as paixões um domínio que amplia nossa soberania. (ARTAUD, 1993, p. 54)

Compreendo que o ofício da atriz, do ator depende menos de um conceito e mais de uma práxis. Tal qual a alma, também a atriz, o ator são signatários de ambiguidades, com as quais faz-se mister conviver, são mensageiros de suas próprias estórias e espelham as estórias do mundo, numa missão arcaica de cura pessoal e coletiva. Nesse sentido, e imbuída de um interesse pedagógico no campo das artes da cena, elaborei a prática da Mitodologia em Arte, defendida no meu doutoramento (UNICAMP, 2011). Este complexo é um caminho em que o artista aperfeiçoa o pluralismo das imagens na sua jornada experiencial. Digo: 
Com inspiração primeiro na ideia de Mitodologia, nomeada por Gilbert Durand (1990), a Mitodologia em Artes Cênicas lida com forças pessoais que movem o atuante na relação consigo mesmo e com o campo artetnografado, num processo contínuo de retroalimentação. Da perspectiva durandiana e seus predecessores estudiosos do imaginário, entendemos que o ser humano tem uma vocação mitológica e ritualística, performática, como também aponta Victor Turner (1974) em seus estudos sobre a Antropologia da Experiência. Há assim uma necessidade vital da imagem e da experiência, uma herança de mitologias, que se põe à prova pelo rito. Desse ponto de vista, o símbolo permite estabelecer o acordo entre o eu e o mundo. Tal constatação conduz a uma transformação epistemológica e metodológica, a qual se distancia de uma estratificação pedagógica de transmissão vertical dos saberes para aproximar-se de certa pedagogia gnóstica, o que Morin (1995) vem a chamar "o método do método". (LYRA, 2011, p. 2).

A Mitodologia em Arte propõe uma episteme particular, uma reconciliação entre poderes da imagem e do símbolo e os poderes do raciocínio na criação cênica, isto é, a interpenetração entre as vias lúdica e intelectiva, estimulando a continuidade entre os imaginários do atuante e de suas máscaras, ligando trajetos pessoais, subjetivos a emanações culturais objetivas do meio cósmico social na pesquisa artística.

Esse caminho de criação acaba por se alicerçar sobre fundamentos arquetípicos, preconizando uma pedagogia do desenvolvimento interior, onde a ação de desenvolver-se estava intimamente ligada à ação de envolver-se do atuante com o processo de criação, na procura em restaurar uma realidade imarginal (imagem e margem), no cultivo da imaginação e na fusão corpo-alma-espírito.

A ludicidade, o atrito da(o) artista com sua vida pessoal e social são pressupostos da Mitodologia em Arte, e para os atos de brincar e cavar o passado individual e coletivo com seus fantasmas e suas luzes, somente um ambiente sedimentado em estados de liberdade e especialmente, de afeto e confiança. E assim surgiu Yriadobá, pela via da Mitodologia em Arte, adentrando o terreno perigoso da pessoalidade, mas tendo o mito africano de Obá como guia e escudo metafórico nesse processo.

De alguma forma, como orientadora do processo criativo com você, Adriana, compreendi a delicadeza dos meandros da investida que se propõe a Mitodologia em Arte. Naturalmente, a ideia de fazer a ebulição de suas memórias não tinha, como na proposição niseana, o intuito de reabilitar de um sofrimento psíquico uma cliente, mas de estimular a elaboração de afetos de uma atriz, potencializando suas sombras e colocando-as ao seu favor na construção de sua ação como atuante na sua vida pessoal, coletiva e engendrando a politização de sua arte, na retomada, por exemplo, de suas ancestrais negras, suas lutas e resistências. 
Figura 1

Partilha Performática Yriadobá da Ira à Flor na Reserva Florestal do Grajaú no Rio de Janeiro, realizada em setembro de 2018. Foto: George Maragaia

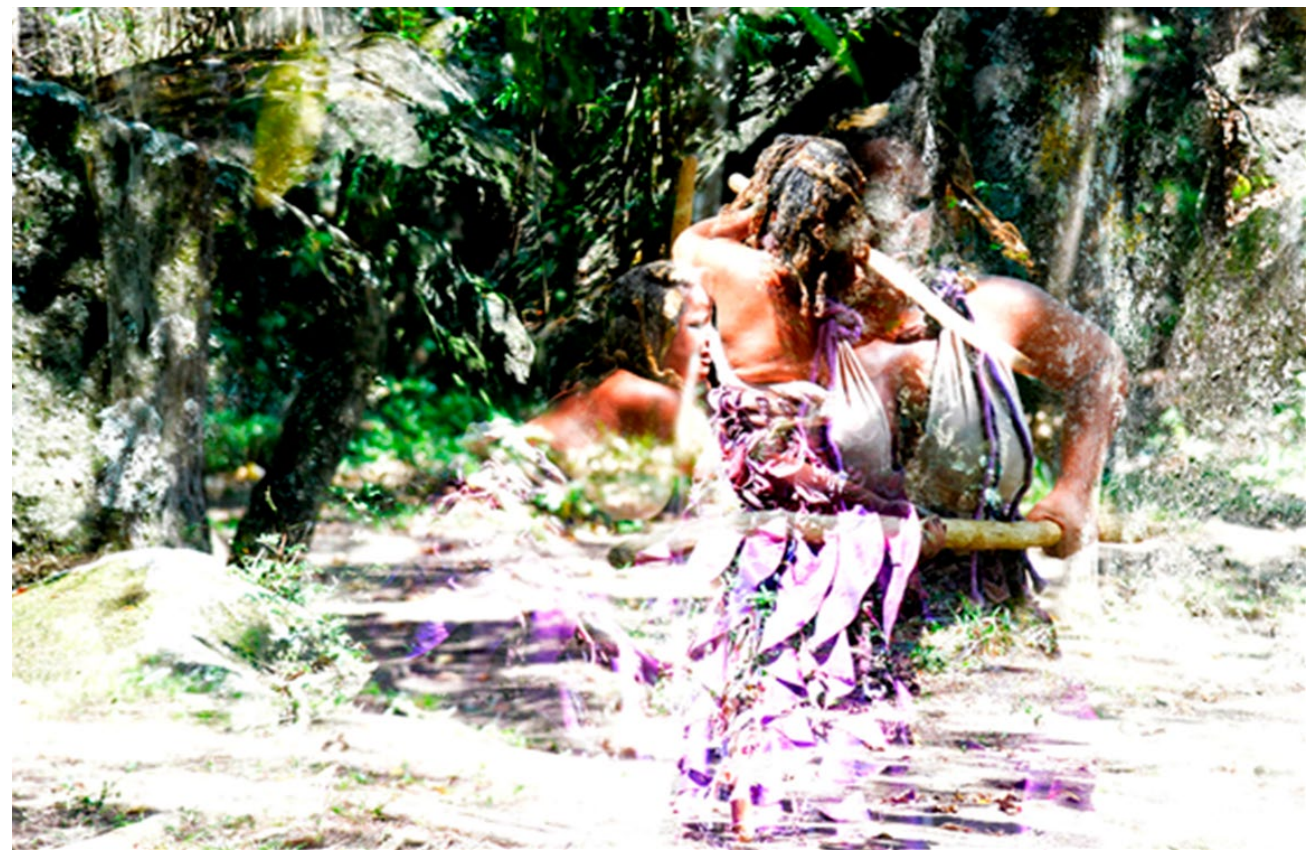

Afinada à Dra. Nise, penso que o aspecto de afecção envolveu todo este processo e foi essencial para a eclosão de Yriadobá. A performance passou a se configurar tanto no plano de seu crescimento individual, como no meu, enquanto condutora. Tanto impactou nos nossos processos de individuação ${ }^{4}$, como também retomamos paisagens culturais devastadoras de nosso passado colonial, tendo o teatro como plataforma para delírios de invenção no sentido da cura. Sinto que fizemos com Yriadobá um caminho de volta, se Nise trafegou da saúde mental para arte, buscamos referências na saúde mental para o alimento de nossa arte.

Figura 2 Qualificação de Mestrado na Reserva Florestal do Grajaú no Rio

de Janeiro, realizada em setembro de 2018 Foto: George Maragaia
4 Relativo ao conceito defendido por Carl Gustav Jung. Individuar-se é o processo de amadurecimento psíquico humano, no caminho de tornar-se único, singular.

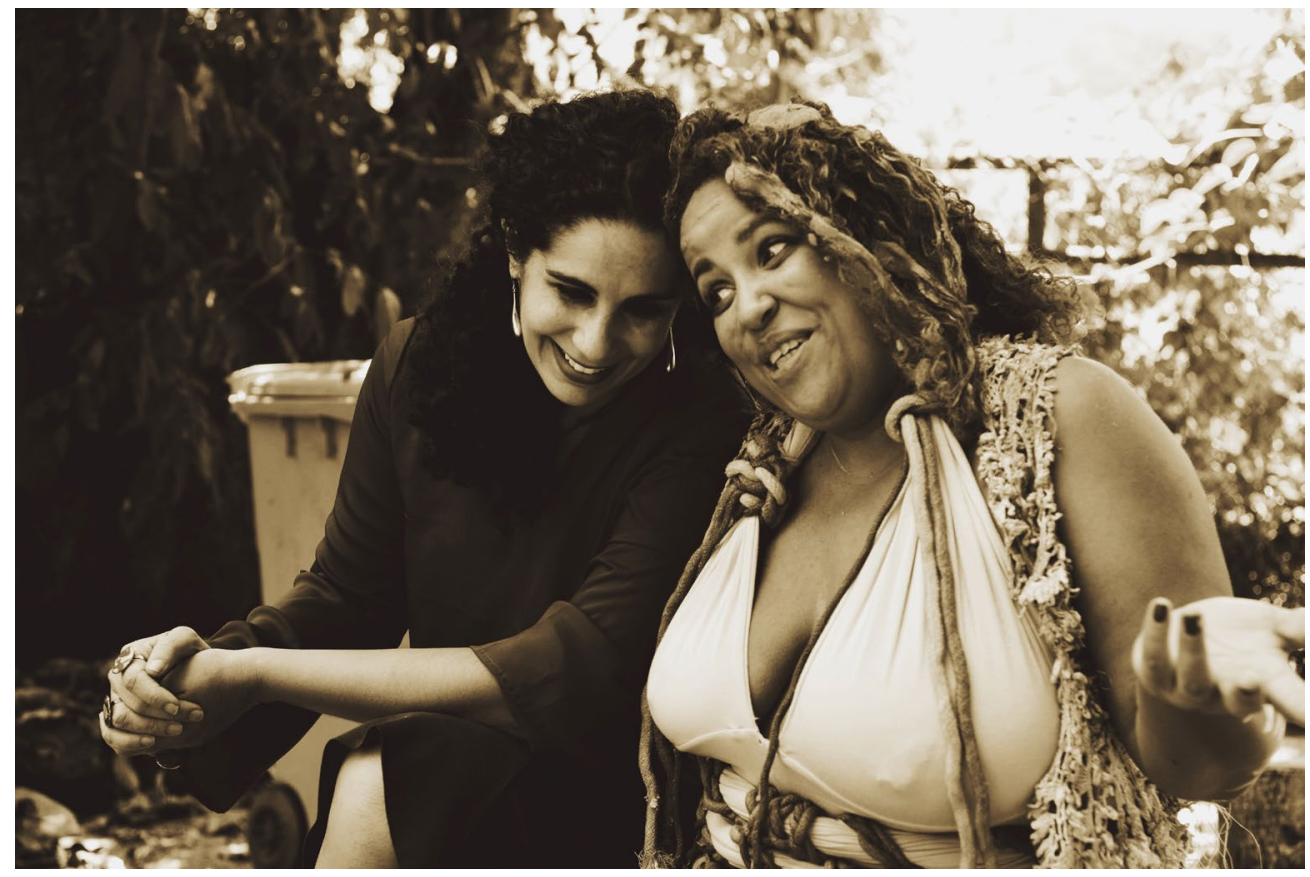


Nunca é pouco dizer quão feliz é nosso encontro e quanto há de pesquisarmos juntas ainda, continuamos agora no museu intimamente ligadas ao pensamento de Dra. Nise. Descubro no ato de te orientar a emoção de lidar ${ }^{5}$. No teatro alquimizamos uma formação em imaginativa onírica fazendo emergir as imagens (imagens de histórias de vida, oníricas e mitos de contos de fadas), definimos as imagens como experiência, reforçamos que elas podem ser primordiais ou ancestrais, pois viajam no espaço e no tempo e têm as suas defesas para se libertarem do intelectivo pensamento. Que possamos seguir às imagens que nos guiam. No Mais, quando for possível, gostaria de te ouvir sobre tudo que te passou desde que nos conhecemos e empreendemos essa jornada de pesquisa e de vida.

Com afeto que não estanca,

Luciana.

Rio de Janeiro, 21 de maio de 2021 (tempos pandêmicos).

Bruxa Luciana,

Olhos marejados, sol do entardecer em cânticos de pássaros que voam livres. Essas são as paisagens que despertam meu movimento de palavrar a emoção de ter você e todo o seu caldeirão performático, acadêmico e curativo na minha vida há quase seis anos. Mas você sabe, esses anos se desdobram em outras vidas e naturezas de outros tempos. Essa tua carta me desloca em várias camadas, foi e continua sendo um mergulho fundo e é mais difícil revisitar essas imagens em experiências no dínamo Yriadobá estando em pandemia e sem te ver de perto há catorze meses.

Quando te conheci, eu era uma mulher casada, me escondia nos moldes heteronormativos e reprimia outros desejos já vividos. Já ressalto o meu pessoal por ter aprendido contigo que ele é também político e acredito que foi essa repressão que alimentou a minha sombra ${ }^{6}$ gerando impulsos violentos do meu animus negativo ${ }^{7}$ e a partir do nosso encontro alquímico

5 Termo também desenvolvido por Nise da Silveira em suas pesquisas com pessoas em sofrimento psíquico.

$6 \mathrm{Na}$ abordagem junguiana, sombra refere-se a conteúdos desconhecidos de si.

$7 \mathrm{Na}$ abordagem junguiana, animus refere-se a energia masculina na psique feminina. 
em laboratório mitodológico eu pude liberar os fluxos em espirais e integrar imagens de meu inconsciente. Eu sempre te entrego esse desconhecido de mim em devir potências, em devir palestras, livros e tantos partos, me tornei parideira depois de ti. Eu só tinha o Cria Jubal lançado, e depois jorrei em criações, parindo Versos, Flores e Vaginas em 2018, Princesa Obá, Yriádobá da Ira à Flor e Ei, Mulher em 2019, foram três livros no mesmo ano, e agora Ritos de Nudez em 2021, todos pela Editora Metanoia. Já dizia Nise da Silveira, 0 que cura fundamentalmente é o estímulo a criatividade.

A jornada em Mitodologia em Arte com as imersões entre os anos de 2017 e 2018, culminando no nascimento do espetáculo de teatro performativo Yriádobá da Ira à Flor ${ }^{8}$, tornou-se uma espécie de função transcendente ${ }^{9}$ no meu processo de individuação. "Essa característica de plenitude descreve um estado anímico que talvez se pudesse caracterizar melhor como um desprendimento da consciência em relação ao mundo e como a retirada da mesma para um ponto por assim dizer extramundano." (JUNG, 1986, p. 28). Recentemente escrevi um artigo para O LIVRO DO MOTIM (LYRA (org.), 2021) e lá desbravei o detalhamento da dramaturgia de Yriádobá e agora sinto vontade de escrever mais sobre o anterior do anterior, a semente fecundada na terra, a reverberação do conceito-prático que você cunhou na tua tese em 2011.

O mito que roçou da minha história nesta vida em laboratórios contigo foi afrodiaspórico e iorubano, trouxe o enegrecimento em Obá e em duas versões, a versão mais propagada e colonial tendo esta deidade como um feminino ferido em pulsões de ira e a versão suleada que conheci através de Mãe Beata de Yemanjá que contou para a abiã ${ }^{10}$ Nairara Paula que me contou e que venho

8 Yriádobá da Ira à Flor é a matrilinearidade entre avós, mães e filhas, é a rainha de 346 mulheres, ela é a Grande Mãe das vaginas humilhadas, dilaceradas, estupradas. Ela desloca a dor em seu peito, com a força da fragilidade, refaz a narrativa e recria o mito. Traz consigo o sopro de milênios e dá corpo às aparições da subjetividade feminina contemporânea com seus ossos de uma fratura que sangra e lateja, revelando o impacto do imperialismo ocidental no inconsciente coletivo, denunciando os sofrimentos das mulheridades silenciadas, invadidas, feridas, das negras, enlouquecidas, que cometeram suicídio num ato de ira, fuga e coragem. Na modalidade espetáculo em palco alternativo tem a duração de cinquenta minutos e na modalidade performance itinerante em área verde são vinte e cinco. Dramaturgia, concepção, direção e atuação: Adriana Rolin. Codireção: Luciana Lyra. Supervisão cênica: Stephane Brodt. Musicista: Lilian Amancai. Composição Musical: Adriana Rolin e Lilian Amancai. Figurino: Adriana Rolin e Bruna Falcão. Adereçamento: Bruna Falcão. Iluminação: César Germano. Cenografia: Adriana Rolin e Humberto Ribeiro. Locais já partilhados: PortoPortugal, Redenção-CE, Belém-PA, Recife-PE, Natal-RN, Brasília-DF, Paraty-RJ, UERJ-RJ, UFF-RJ, Museu de Imagens do Inconsciente-RJ e Reserva Florestal do Grajaú-RJ.

$9 \mathrm{Na}$ abordagem junguiana refere-se a integração de conteúdos do inconsciente coletivo e individual.

10 Na hierarquia do candomblé, abiã é começo e pé da história, até torna-se iaô que é iniciada. 
contando nas travessias, com Oxum em complementariedade na feitiçaria sobre o poder feminino em rios, pororocas, cavernas e outros fenômenos.

A concepção ancestral africana inclui, no mesmo circuito fenomenológico, as divindades, a natureza cósmica, a fauna, a flora, os elementos físicos, os mortos, os vivos e os que ainda vão nascer, concebidos em contínuo processo de transformação e de devir". (MARTINS, 2012, p. 13).

Tendo essas narrativas em tessituras com tua tese de doutoramento, que já convido aos leitores e leitoras desta carta-artigo, a buscarem no repositório da UNICAMP Guerreiras e Heroínas em Performance: da Artetnografia à Mitodologia em Artes Cênicas (LYRA, 2011) com os detalhamentos dos diversos procedimentos criados por ti e que me contagiaram intimamente, sobretudo Alquimia dos Elementos, Os Descansos, Objetos Sagrados, Totem Animal, As Vestes Rituais, O Batismo e Mandala Cartográfica.

Luciana, os quatro elementos da natureza em alquimia conduzidos por sua voz em concomitância aos cháckras foram aparições de intensidades em pélvis e fogo, encaminhadas nas mortes transformadas em vidas e as minhas raivas ressignificadas em potências sedimentadas nos descansos e decantos. Aí nos objetos tão sacralizados e ritualizados aos seus olhos-testemunhas, pude navegar na complexidade entre guerra e amor, traduzidos na adaga e na moringa e em animal, as circularidades da serpente em unusmundus ${ }^{11}$ de contínuos feixes do meu corpo-alma-espírito. Mas as vestes em segunda pele, no seio natural, em águas e florestas juntamente do batismo na cachoeira da Cascatinha Taunai, foram os procedimentos que mais marcaram para mim, me emociono outra vez, aquele arroxeado em canções e ressonadores tão meus e teus, movendo da ira à flor, e enfim a mandala com cartografias afetivas que estruturaram a cena performática.

Já te contei, mas quero dar um grifo que neste processo de criação fui visitada também por imagens do inconsciente coletivo através da amplificação ${ }^{12}$ do símbolo da orelha mutilada de Obá no portal da matrilinearidade em correlação a vagina abusada e invadida. Na África, a orelha simbolizava sempre a animalidade. Para os dogons e os bambaras do Mali, a orelha é um duplo símbolo sexual: o pavilhão representando um pênis, e o conduto auditivo, uma vagina. (CHEVALIER e GHEERBRANT, 1982, p. 661). No início

$11 \mathrm{Na}$ abordagem junguiana refere-se à totalidade dos mundos interno e externo.

$12 \mathrm{Na}$ abordagem junguiana refere-se a um movimento circular em torno de um ponto específico. 
eram as mutilações de minha vagina que apareciam na dramaturgia, depois surgiram as mutilações nas vaginas de minha mãe e de minha avó materna, que ganhou certo protagonismo, por ser mulher negra, considerada enlouquecida, que sofrera violências múltiplas e cometera suicídio ateando fogo em si mesma num ato de fuga e coragem, denunciando a pulsão patriarcal e racista na figura de meu avô.

Mais do que Arlete, Yriadobá precisou aparecer para refazer o mito e nos dizer no alto das montanhas, esse neologismo que você me presenteou, Luciana. Te convido a ler e ouvir tua voz ecoando Y-r-i-a-d-o-b-á, gosto da última sílaba bem acentuada que precede um silêncio em suspensão, ela é neta do sol e prima da lama, ela carrega no peito o grito de 346 mulheres humilhadas, dilaceradas, mortas. Sinto-a como um resgate de mim e de minhas ancestrais, é sempre um ritual de cura trazê-la em cena e muitas vezes canto as canções que lhe compus quando me sinto em escuridão porque também fui visitada por imagens de suicídio ao longo desse processo, mas era a janela do oitavo andar que me convidava a saltar em voos e céus, era o ar e não o fogo, eram asas e flores que despetalavam até o cair do chão. Arlete me ensinou a reolhar o impacto do racismo na saúde mental da população negra porque também sou negra e habito espaços hegemônicos. "A complexidade histórica-política, econômica, cultural e social do Brasil se reflete no aspecto intra e inter-psíquico da população brasileira e nos seus mecanismos de perpetuação do racismo." (MOTA, 2019, p. 36).

\begin{abstract}
Sou neta do sol, prima da lama, caminho há milênios por terras desérticas e só descanso tendo o último grito da mulher humilhada, dilacerada, morta. Sou a última da linhagem e vim aqui dizer. Não ousem estuprar nossa subjetividade porque eu apareço das montanhas, o meu murmúrio tem a vida de 346 mulheres, destrói uma cidade inteira pelo fogo. Sou a dona da vida e da morte, navego no entre dois, eu mato sim, não me curvo diante de patriarcado nenhum e não permito que vagina nascida de meu ventre amamente o falo cortante. Nós fomos subjugadas por tempo demais que vocês pensaram que não iríamos nos reerguer, não é? Mas agora eu estou aqui, elas me movem e me pedem para fazer isso. Eu sou a imagem que chega em mim, me derreto assim em rios, eu cerco o mar todos os dias e vento, vento sim, ai de mim se eu não ventasse. Tenho ventoinhas no self de minha lua que me diz baixinho: Deixai ir este delírio, transformai em terras de lírio. Eu moro nas margens, tenho um abismo a beira de meus olhos e o cajado está comigo. Lembra-te, agora sou Yriadobá. Eu queria ser árvore, mas nasci mulher. (ROLIN. 2019, p. 73).
\end{abstract}

Luciana, eu sempre preciso de tempo depois de convocar Yriadobá, é um volume denso das afecções, memórias dos festivais e congressos, circulamos por Redenção, Recife, Belém, Natal, Brasília e até Porto em Portugal, além do Rio de Janeiro em multiplicidades, caminhei largas passadas numa espécie de respiro para retomar-te em carta. Vou puxar por este fio do afeto para o decorrer dos próximos parágrafos porque assim como você e Nise da 
Silveira, nesses doze anos em que venho pesquisando Antonin Artaud e suas reverberações, aprendi que a quebra da representação no teatro começa pelo Duplo de Afetividades.

É sobre esse duplo que o teatro influi. A memória do coração é durável e sem dúvida, o ator pensa com o coração. Isso significa que no teatro, mais do que qualquer outro lugar, é no mundo afetivo que o ator deve tomar consciência. (ARTAUD, 2006, p. 153).

Também sobre pensar com o coração, a prof. Verônica Fabrini, que conheci através de você e esteve na minha banca de mestrado, tem um artigo sobre o sul do saber e o sul da cena. Lá diz ela:

Isto não implica apenas numa tomada de posição intelectual, mas é também uma tomada em direção a uma posição ético-afetiva e uma descida ao sul da cabeça, uma descida ao coração. (FABRINNI, 2013, p. 23).

Vejo o nosso processo em Yriádobá nestes lugares citados por Artaud e Fabrini, e recentemente nos encontros do nosso grupo de pesquisa MOTIM - Mito, rito e cartografias nas artes (CNPq) você nos orientou a estudar Suely Rolnik em Esferas da Insurreição que também quero ressaltar.

É que não se trata aqui de uma emoção psicológica, mas sim de uma emoção vital, a qual pode ser contemplada pelo sentido do verbo afetar - tocar, perturbar, abalar, atingir; sentido que, no entanto, não se usa em sua forma substanciada. (ROLNIK, 2018, p. 37).

Sobre essa energia vital gostaria de dar um negrito, porque nos ensinamentos de terreiro que venho trafegando como alafetibó, essas são as características do axé e também das energias circulares em Esù que catalisam vida e eu fico me perguntando qual seria o desdobramento do afeto catalisador em Nise se ela tivesse bebido nessas fontes e também se Artaud tivesse mergulhado nas matrizes africanas além das tribos indígenas tarahumaras.

Inclusive por isso tenho reunido no meu caldeirão de pesquisa de doutoramento sob sua orientação, os escritos metafóricos de Antonin Artaud, as proposições junguianas e niseanas, algumas técnicas do APA (Ateliê de Pesquisa do Ator) e a mitologia yorubá em sabenças do llê Asè Ogum Alakorô com o Baba Paulo de Ogum para criar um caminho pedagógico para as artes da cena, entendendo este caminho como curativo e terapêutico com os Influxos Artaudianos, nome batizado por ti, em laboratórios de investigação no Museu de Imagens do Inconsciente e no Centro de Cultura da Universidade do Estado do Rio de Janeiro, entendendo os meandros da arte como saúde, por ser também arteterapeuta além de atriz. 
Lyra querida, quanto tempo não te chamo pelo sobrenome, tenho oferta poética sobre esse tema, escrevi semana passada, espero que goste.

\author{
CORPO DE AXÉ \\ Ele abre, alastra o fogo e gira a ginga \\ Senhor dos duplos em raízes espirais \\ Laroyê, eu saúdo teus órgãos ancestrais. \\ Tridimensional, fluxo do desconhecido \\ Corpo vibrando riso, gozo em falos e frestas \\ Vermelha eu danço outras manifestas. \\ Movimento brincante de encante e axé \\ Reticência que pulsa vida em presságio \\ Energia catalisadora em cruzos e contágio. \\ Exú é rei nas ruas, casas, entres e caminhos \\ Boca que abre, lambe, engole, boca que come \\ Ele é palavra que corta, refaz qualquer pronome.
}

Já entrando em ritos finais, quero te contar em suma como tem sido a experiência de mediar o grupo Os Inumeráveis com treze clientes-artistas do Museu de Imagens do Inconsciente desde 13 de junho de 2019, dia de Esù. Mas você sabe, meu diálogo neste território foi iniciado antes de te conhecer, através do Prof. Maddi Damião (UFF), que é também meu co-orientador do doutorado e foi meu orientador da pesquisa Lapso Falho e Processos de Criação: A Experiência do Sagrado no Teatro da Crueldade na especialização em Arteterapia Junguiana em que entrecruzei Antonin Artaud e Carl Gustav Jung e precisei fazer estágio supervisionado lá em 2015 e o Museu abrigou o então grupo Corpo-Criação sob minha mediação com seis clientes-artistas, culminando nas performances O Dragão-Baleia e O Conto do Boto-Rosa. Naquele período eu já utilizava de proposições artaudianas mas os contos e mitos não estavam suleados na cultura afrodiaspórica.

Os Inumeráveis é em homenagem à Nise que sempre proferia a frase de Artaud 'o ser tem inumeráveis estados e cada vez mais perigosos' porque ela não gostava da palavra esquizofrenia. Antonin Artaud foi ator, pintor surrealista, dramaturgo, poeta, diretor de teatro, escreveu mais de vinte e oito obras, foi considerado esquizofrênico e escrevia para não perder a lucidez. Lá com os clientes-artistas do Museu em seus inumeráveis estados do ser, eu venho utilizando as seguintes proposições artaudianas: Duplo de Afetividades, Vibração de Sons Incomuns, Glossolalia, Lugar Único sem Divisão, Metafísica Animal, Teatro Mítico, Mágico e Ritual.

Já temos uma performance em nosso repertório, lembra? Chama-se Sekhmet: A Incendiária com base no mito egípcio Basteti e Sekhmet sobre a união dos opostos amor e fúria, gata e leoa da psique feminina. Esta performance foi 
partilhada na Primavera dos Museus que teve sede no Instituto Municipal Nise da Silveira, na Espiral dos Afetos que teve sede no Centro de Artes da Universidade Federal Fluminense, além da estreia ter sido no grupo de estudos do MII contando com sua linda presença.

Quando a pandemia mundial da Covid19 se instaurou, o grupo Os Inumeráveis se manteve ativo através do whatsapp por seis meses em que eu enviava vídeo sempre no mesmo horário de nossas atividades presenciais, terças-feiras às 10h. Eram contos de diversas culturas e algumas tímidas propostas da arte da presença em ressignificação nesta plataforma, e que, geraram inúmeras obras digitais compartilhadas por eles e elas, sendo armazenadas no Acervo Digital da Quarentena do Museu, que hoje contabilizam-se trezentas e trinta e duas, entre pinturas, desenhos, escritas, poesias, vídeos performáticos, composições musicais, estórias contadas e gestos fotográficos.

Mais a frente, em reunião de equipe do Museu, fui provocada por Gladys Shincariol a transpor Os Inumeráveis para a plataforma zoom e ampliar as linguagens da arte através das colaboradoras Adriana Barcellos que é arteterapeuta, bailarina e doutora em artes cênicas, Giulia Drummond que é cantora, compositora e musicista e, Adriana Lemos que é psicóloga. Abracei esse desafio como um polvo no fundo do grande mar e aqui sua orientação, bem como a de Maddi me levaram a reafirmar a mitologia yorubá neste espaço, coisa que eu ainda não me encorajava. Foram mais seis meses em estudos dos arquétipos Esù, Ogum, Oxóssi, Ossãin e Omolú, os cinco primeiros deste $x i r \hat{e}^{13}$, correlacionando a Psicologia Analítica e costurando as mediações de teatro, dança, música e roda de conversa.

Os encontros por zoom têm tido uma aderência bem bonita e Gladys nos convidou para integrar uma coluna do Jornal Universo que está prestes a ganhar um novo formato. Recordo-me com largo sorriso da confraternização de fim de ano e também do baile de carnaval em que diversos profissionais e outros clientes-artistas atendidos no Museu estiveram conosco vibrando em corações pulsantes, e agora estamos trilhando a estreia de nossa próxima performance de construção coletiva tendo os mitos iorubanos como terreno fecundo, chama-se O Ritual das Árvores e Flores em Pássaros Cantantes.

Esses são os principais símbolos que amplificamos em título, pois eles se repetem em contágios expressivos dos clientes-artistas que criaram seus

13 Na cultura iorubana, xirê significa a roda de evocação aos orixás. 
Figura 3

Estreia de Sekhmet: A Incendiária no grupo de estudos do Museu de Imagens do Inconsciente realizada em agosto de 2019. Self por Luciana Lyra

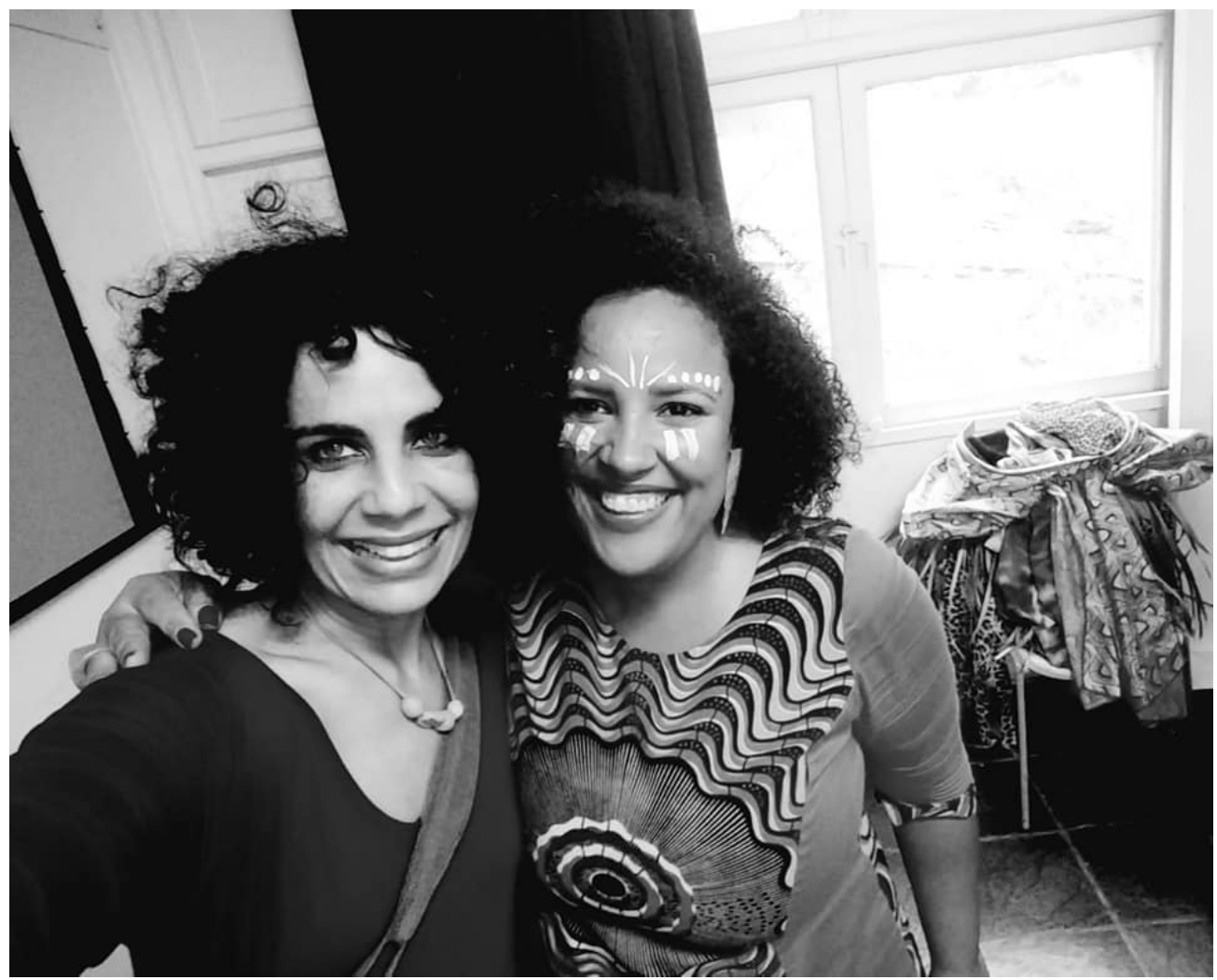

personagens, tais como Mensageiro Transformer, Guerreiro da Flecha Invisível Ubiratã, Princesa do Reino das Mangas, Rainha do Baobá, Coração de Flores Sensíveis da Floresta, entre outros. Alguns nomes já denunciam em quais arquétipo nasceram, mas, mesmo assim, quero te contar os ítans ${ }^{14}$ que utilizei nessa jornada: Esù ganha poder sobre as encruzilhadas; Ogum faz instrumentos agrícolas para Oxaguiãn; Oxóssi mata o pássaro das feiticeiras; Ossãin recusa-se a cortar as ervas miraculosas e Obaluaê tem as feridas transformadas em pipoca por Oyá.

Você sabe que o teatro artaudiano é da experiência e não da representação, é da intensidade e não da intenção e é da aparição e não da aparência e tem sido precioso testemunhar o movimento integrador dos processos de individuação, outro dia te mostro em detalhes as pinturas e as poesias em áudios de uma cliente-artista que segundo Gladys está no abraço da grande mãe, está num momento muito interessante, em pleno desenvolvimento da consciência. Foi emocionante vê-la criando um mitema sobre a cura de Omolú na dança de Oyá: "ele foi curado pelo olhar, é a cura mais poderosa, é a cura

14 Na cultura iorubana, ítan significa passagem, trecho ou cena de um mesmo mito. 
Figura 4

Partilha Performática de Sekhmet: A Incendiária na Espiral dos Afetos da Universidade Federal Fluminense, realizada em outubro de 2019. Foto: Marcelo Valle

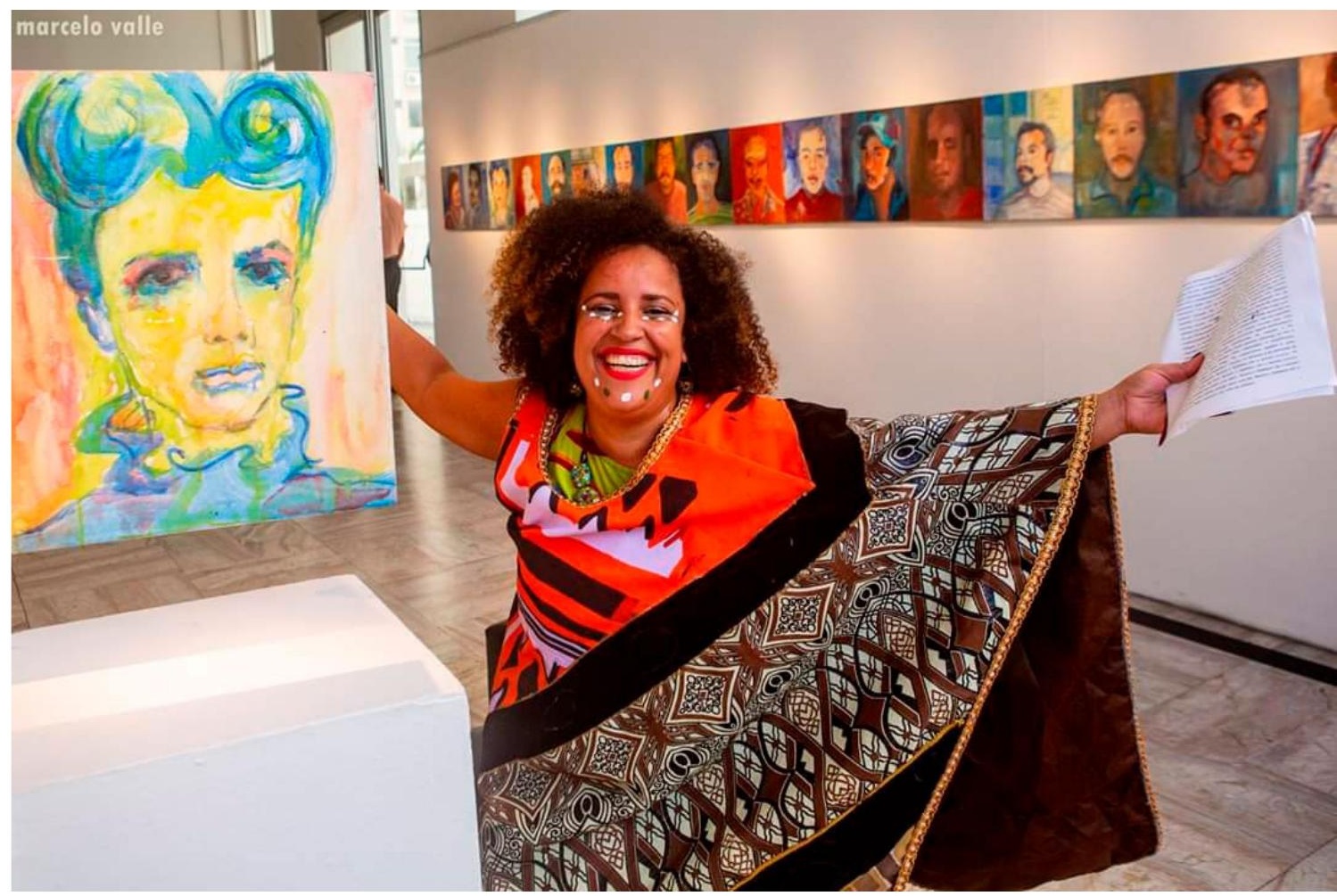

que vem de dentro." Quando tiver mais tempo, quero te mostrar os vídeos e as composições musicais de outra cliente-artista, ela é negra e retinta, dia desses trafegamos por sua história de vida e segundo Gladys os temas abordados no teatro têm inspirado ao retorno à natureza e tem ajudado na sua consciência fincada na terra. Ela vai protagonizar a próxima performance, espero te ver lá, a estreia vai ser no GE do MIl em julho via zoom.

Termino esta carta te agradecendo grandemente pelo banho de folhas, é rito curativo por via da escrita. É ebó ${ }^{15}$ de fechamento de xirê, lembrando que findar é abrir, o processo é espiral. Desejo vacina em segunda dose tão logo, saudade de ti. Que possamos partilhar Yriadobá em terras e atlânticos mais distantes.

Beijos, Rolin. 


\section{Referências}

ANTONIN, Artaud. O Teatro e seu Duplo. São Paulo: Martins Fontes, 1993.

CHEVALIER e GHEERBRANT. Dicionário dos Símbolos. 31ª edição. Rio de Janeiro: Ed. José Olympio, 1982.

COHEN, Renato. Performance como Linguagem - Criação de um espaçotempo de experimentação. São Paulo: Editora Perspectiva, 2007.

FABRINI, Verônica. Sul da cena, sul do saber. Campinas: UNICAMP, 2013.

JUNG, Carl Gustav. O Homem e os seus Símbolos. Rio de Janeiro: Nova Fronteira, 1964.

Memórias, Sonhos e Reflexões. Rio de Janeiro: Nova

Fronteira, 1986.

DURAND, Gilbert. Mito, símbolo e mitodologia. Lisboa: Editorial Presença, 1990.

LYRA, Luciana de Fátima Rocha Pereira de. Guerreiras e Heroínas em Performance. Da Artetnografia à Mitodologia em Artes Cênicas. 2011. Tese (Doutorado em Artes Cênicas), Instituto de Artes. Universidade Estadual de Campinas (UNICAMP), Campinas-SP, 2011.

- Mitodologia em Artes Cênicas: Diretrizes,

pressupostos, princípios e procedimentos para criação. Anais da ABRACE, 2011.

(Org.). O Livro do Motim. São Paulo. Paco Editoria,

2021.

MARTINS, Leda Maria. Performances da oralitura: corpo, lugar de memória. Minas Gerais: Línguas e Literaturas: Limites e Fronteiras, 2019.

MELO, W. Nise da Silveira. Rio de Janeiro/Brasília: Imago/CFP, 2001.

. Nise da Silveira, Antonin Artaud e Rubens Corrêa:

fronteiras da arte e da saúde mental. Gerais: Revista Interinstitucional de Psicologia, 2(2), 182-191, 2010.

MELLO, Luiz Carlos. Nise da Silveira: caminhos de uma psiquiatra rebelde. Rio de Janeiro: Automatica edições, 2014.

MOTA, Bruno. Na teia do racismo: trauma coletivo e complexo cultural, marcas do Brasil negro. 2019. Dissertação (Mestrado em Psicologia). Universidade Federal Rural do Rio de Janeiro (UFRRJ), Rio de Janeiro, 2019. 
PEDROSA, M. Introdução. In M. Pedrosa. Museu de Imagens do Inconsciente (pp.9-11). Rio de Janeiro: Funarte, 1980.

ROLIN, Adriana. Yriádobá da Ira à Flor. Rio de Janeiro: Ed. Metanoia, 2019. . Influxos Artaudianos via Cartografia do Sul. Artigo. Revista Conccinitas: UERJ, ano 19, número 34, dezembro de 2018.

- Yriádobá Da Ira à Flor: Influxos Artaudianos via

Mitodologia em Arte. 2019. 219 f. Dissertação (Mestrado em Artes). Universidade do Estado do Rio de Janeiro, Rio de Janeiro, 2019.

ROLNIK, Suely. Esperas da insurreição: notas para uma vida não cafetinada. Rio de Janeiro: N-1 Edições, 2019.

SILVEIRA, Nise. Imagens do inconsciente. Rio de Janeiro: Alhambra, 1981. . O mundo das imagens. São Paulo: Ática, 1992.

VERGER, Pierre. Lendas Africanas. Rio de Janeiro. Ed: Fundação Pierre Verger, 1997. 